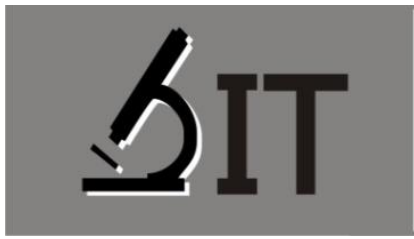

p-ISSN : 2597-8977

e-ISSN : 2597-8985

Dwi Widyawati *)

Universitas Bengkulu

Dewi Jumiarni

Universitas Bengkulu

Irwandi Ansori

Universitas Bengkulu
JIT 5 (1) (2021) 75-84

JURNAL IPA TERPADU

http://ojs.unm.ac.id/index.php/ipaterpadu

\section{PENGEMBANGAN MULTIMEDIA INTERAKTIF BERBASIS MACROMEDIA FLASH \\ PADA MATERI FOTOSINTESIS KELAS XII SMA}

Abstrak: Penelitian ini bertujuan untuk mendesain multimedia interaktif menggunakan aplikasi komputer yaitu Macromedia Flash. Multimedia interaktif ini digunakan sebagai media untuk pembelajaran pada materi fotosintesis untuk kelas XII SMA. Subjek penelitian ini adalah 10 orang peserta didik kelas XII MIPA Sekolah Menengah Atas Negeri 1 Kepahiang. Teknik pengumpulan data pada penelitian ini adalah angket (kuisioner). Instrumen yang digunakan adalah lembar angket (kuisioner) untuk dua orang validator (dua orang Dosen Program Studi Pendidikan Biologi) dan satu orang guru Biologi SMA sebagai subjek uji kepraktisan dan lembar uji respon untuk peserta didik. Berdasarkan hasil validasi oleh validator, multimedia interaktif yang dikembangkan dinilai sangat layak digunakan sebagai media pembelajaran dengan nilai rata-rata $89,69 \%$. Hasil uji respon oleh peserta didik juga memperoleh predikat sangat baik dengan nilai rata-rata $86,73 \%$. Berdasarkan hasil uji validitas dan respon tersebut, multimedia interaktif yang dikembangkan ini layak digunakan sebagai bahan ajar untuk materi fotosintesis pada kelas XII SMA.

Kata Kunci: Fotosintesis Macromedia Flash Multimedia interaktif

Abstract: This study aims to design interactive multimedia using a computer application, namely Macromedia Flash. This interactive multimedia is used as a learning medium in photo-synthesis material for class XII SMA. Interactive multimedia developed is designed by considering the needs of students in class XII SMA and biology subject teachers, namely by conducting interviews with teachers, analyzing curriculum, and literature study on interactive multimedia and photosynthesis material for class XII SMA. The developed interactive multimedia contains several photosynthesis sub materials for class XII SMA. The developed interactive multimedia was tested for its feasibility with three validators, namely a media expert lecturer, a material expert lecturer, and a biology teacher for class XII of SMA Negeri 1 Kepahiang as practitioner experts. The results of the feasibility test by three experts showed a percentage of $89.69 \%$ with a very feasible category. In addition to the feasibility test, there was also a response test for interactive multimedia that was developed for 10 students of class XII MIPA at SMA Negeri 1 Kepahiang with a percentage of $86.73 \%$ in the very feasible category. Interactive multimedia, Macromedia Flash, Photosynthesis.

Keyword: Interactive multimedia, Macromedia Flash, Photosynthesis

*) Correspondence Author: Dwiwidya70o@gmail.com 


\section{PENDAHULUAN}

Media pembelajaran berbasis multimedia merupakan media pembelajaran yang memanfaatkan penggabungan antara gambar, suara atau audio, dan video. Menurut Mayer (2009) multimedia merujuk pada presentasi dengan menggunakan kata-kata dan gambar-gambar. Kasus yang mendukung multimedia ini terletak pada premis bahwa learner lebih bisa memahami penjelasan jika disampaikan dalam kata-kata dan gambar-gambar daripada jika disajikan hanya dalam kata-kata. Fitur multimedia seperti video dan animasi dapat menjadi sarana untuk menyampaikan materi secara lebih konkret atau nyata.

Penggunaan media pembelajaran dimaksudkan untuk memberi kemudahan dalam proses belajar mengajar. Media pembelajaran dapat dibuat dalam berbagai bentuk sesuai dengan kebutuhan dan karakteristik materi ajar yang akan disajikan (Sari dkk, 2020). Menurut Noer (2010) mengungkapkan bahwa ketika peserta didik menerima pesan dengan segala aktivitas inderawinya, baik melalui pendengaran, penglihatan serta perbuatannya maka mereka memproses dan menerima lebih dari 100.000.000 bit data per detik. Oleh sebab, itu untuk meningkatkan aktivitas belajar peserta didik dengan memaksimalkan kerja inderanya penggunaan media pembelajaran berbasis teknologi berupa multimedia interaktif ini sangat dianjurkan.

Salah satu program komputer yang mampu mengembangkan media pembelajaran berupa multimedia interaktif, yaitu dengan menggunakan Macromedia Flash. Macromedia Flash adalah salah satu program yang dapat digunakan untuk membuat suatu karya animasi, tidak sedikit para animator membuat beragam animasi, seperti animasi interaktif maupun non interaktif. Menurut Sutopo (2003) Macromedia Flash sebagai media pembelajaran dapat di akses dengan mudah oleh siswa melalui personal computer di rumah atau di tempat lain selain di sekolah (pembelajaran secara daring). Materi yang disajikan dalam penggunaan Macromedia Flash ini dapat disesuaikan dengan kebutuhan guru dan siswa. Penggunaan Macromedia Flash dapat mewadahi beberapa macam teks, chart, audio, animasi, simulasi, atau foto. Macam-macam komponen tersebut bila digabungkan menjadi satu akan menghasilkan sumber belajar secara interaktif dan menghasilkan suatu pembelajaran yang efektif.

Berdasarkan hasil wawancara dengan salah satu guru mata pelajaran Biologi di SMA Negeri 1 Kepahiang diketahui bahwa minat belajar peserta didik kelas XII terhadap materi Fotosintesis tergolong rendah. Hal tersebut terlihat dari berbagai aspek dalam proses KBM (kegiatan belajar mengajar) didalam kelas, salah satunya adalah bahwa peserta didik kurang antusias ketika guru menjelaskan materi tentang fotosintesis di depan kelas meskipun sebelum pelajaran berlangsung guru sudah memberikan apersepsi. Selain itu, peserta didik kurang merespon saat guru memberikan beberapa pertanyaan terkait materi fotosintesis, dan media pembelajaran yang digunakan oleh guru dalam menyampaikan materi fotosintesis ini kurang bervariasi sehingga konsep-konsep pada materi fotosintesis ini tidak dapat tersampaikan dengan baik kepada peserta didik, hal tersebut juga membuat peserta didik sering mengalami miskonsepsi pada konsepkonsep yang ada pada materi fotosintesis. Pada materi fotosintesis ini banyak konsep-kosep yang sukar difahami oleh peserta didik.

Materi fotosintesis ini bersifat abstrak (proses-proses yang terjadi dalam fotosintesis tidak dapat diamati langsung oleh peserta didik maupun guru) karena proses fotosintesis hanya bersifat semu dalam bayangan peserta didik. Sulamtina (2017) menyatakan bahwa miskonsepsi yang terjadi pada konsep fotosintesis diantaranya adalah: (1) fotosintesis merupakan proses pengambilan Oksigen dan pelepasan Karbon Dioksida pada tumbuhan; (2) fotosintesis sama dengan respirasi; (3) glukosa adalah hasil akhir dari fotosintesis; (4) tumbuhan disebut produsen karena menghasilkan Oksigen; (5) hanya tumbuhan hijau yang dapat melakukan fotosintesis.

Penelitian yang relevan dengan pengembangan multimedia interaktif menggunakan Macromedia Flash telah dilakukan oleh Kusumawanto (2011) yang mengembangkan media pembelajaran Macromedia Flash pada mata pelajaran Kompetensi Dasar Teknik Mesin di SMK N 2 
Pengasih Kulon Progo Yogyakarta diperoleh rerata persentase validasi sebesar 83,04\% dan rerata persentase uji coba media sebesar $84,14 \%$. Sehingga media pembelajaran yang dikembangkan layak digunakan sebagai media pembelajaran pada mata pelajaran kompetensi dasar teknik mesin pada standar kompetensi menjelaskan proses dasar perlakuan logam.

Penelitian tentang Pengembangan Multimedia Interaktif menggunakan Macromedia Flash juga dilakukan oleh Meitantiwi (2015) yang mengembangkan Multimedia pembelajaran tutorial pada materi sifat keperiodikan unsur untuk yang dikembangkan memiliki kelayakan yang baik berdasarkan rerata persentase validasi sebesar $80,63 \%$ dan uji coba produk sebesar $91,86 \%$ serta memiliki efektivitas yang baik untuk pembelajaran kimia dengan adanya perbedaan rata-rata hasil tes yang lebih baik pada kelas perlakuan dibandingkan dengan kelas tanpa perlakuan.

Oleh sebab itu, dilakukan penelitian berupa pengembangan media pembelajaran untuk memperbaiki kualitas pembelajaran terhadap materi fotosintesis pada kelas XII SMA berupa multimedia interaktif berbasis Macromedia Flash. Penelitian ini diharapkan mampu menghasilkan suatu media pembelajaran Biologi berupa multimedia interaktif yang menjelaskan materi Fotosintesis, sehingga dapat menarik minat belajar peserta didik serta meningkatkan pemahaman peserta didik terhadap materi tersebut.

\section{METODE}

Penelitian ini merupakan model pengembangan dalam penelitian ini menggunakan langkah- langkah dari Borg \& Gall, yang telah disederhanakan menjadi lima langkah utama oleh Tim Puslitjaknov yang disederhanakan lagi menjadi 4 langkah yaitu; (1) Melakukan analisis produk yang akan dikembangkan, (2) Mengembangkan produk awal, (3) Validasi ahli, dan (4) Uji lapangan skala kecil berupa uji respon. Penyerdahanann ini dilakukan sesuai dengan kebutuhan peneliti tanpa mengurangi substansi langkah-langkah penelitian dari Borg \& Gall. Subjek dalam penelitian ini berjumlah 1 orang dosen ahli media, 1 orang dosen ahli materi, 1 orang guru mata pelajaran Biologi kelas XII SMA Negeri 1 Kepahiang dan 10 orang peserta didik kelas XII MIPA SMA Negeri 1 Kepahiang tahun ajaran 2020/2021 yang dipilih secara acak. Teknik pengumpulan data pada penelitian ini yaitu wawancara dan angket. Data hasil validasi dan uji respon yang merupakan data kuantitatif yang diubah menjadi data kualitatif kemudian dianalisis secara deskriptif kualitatif. Skor yang didapat dari hasil lembar validasi dan uji keterbacaan dianalisis dengan rumus:

$$
\text { Jumlah skor lembar validitas }
$$

Presentase $=$

Skor maksimal

Hasil analisis data yang berupa persentase tersebut kemudian diinterpretasikan pada Tabel 1 berikut.

Tabel 1. Kriteria Penilaian Hasil Validasi dan Uji Respon

\begin{tabular}{cc}
\hline Persentase & Kriteria \\
\hline $0 \%-20 \%$ & Sangat Tidak Valid \\
$21 \%-40 \%$ & Tidak Valid \\
$41 \%-60 \%$ & Cukup valid \\
$61 \%-80 \%$ & Valid \\
$81 \%-100 \%$ & Sangat Valid \\
\hline
\end{tabular}

(Riduwan, 2015) 


\section{HASIL DAN PEMBAHASAN}

Penelitian pengembangan ini mengacu pada langkah-langkah penelitian dan pengembangan Borg \& Gall yang telah disederhanakan oleh Tim Puslitjaknov menjadi 5 langkah dan kembali disederhanakan oleh peneliti sehingga menjadi 4 langkah penelitian pengembangan, yaitu; 1) Melakukan analisis produk yang akan dikembangkan, 2) Mengembangkan produk awal, 3) Validasi ahli dan revisi, 4) Uji lapangan skala kecil. Adapun hasil dan pembahasan dari setiap langkah- langkah penelitian yang dilakukan adalah sebagai berikut:

\section{a. Analisis Produk yang dikembangkan}

1. Produk awal berupa multimedia interaktif pada mata pelajaran biologi kelas XII SMA berdasarkan atas analisis kebutuhan dengan mewawancarai guru mata pelajaran Biologi yang mengajar kelas XII MIPA. Pembuatan desain multimedia Interaktif dilakukan dengan cara menyusun flowchart dan storyboard serta pembuatan desain dengan mengumpulkan bahan-bahan pendukung seperti kajian materi dari berbagai literatur baik itu dari buku paket Biologi kelas XII SMA, menganalisis beberapa jurnal yang berkaitan dengan materi fotosintesis dan beberapa buku penunjang penggunaan Macromedia Flash, dilakukan pula pengeditan dan mencampurkan bahan- bahan pendukung untuk menghasilkan suatu multimedia interaktif materi Fotosintesis untuk kelas XII SMA serta menganalisis kurikulum yang digunakan pada mata pelajaran Biologi kelas XII.

2. Analisis kurikulum meliputi kegiatan menganalisis kurikulum yang dipakai di SMA dan Kompetensi Dasar (KD) yang dipakai dalam pembelajaran biologi pada materi Metabolisme khususnya pada sub materi Fotosintesis kelas XII yaitu pada KD 3.2. Menjelaskan proses metabolisme sebagai reaksi enzimatis dalam makhluk hidup.

3. Pemilihan materi fotosintesis ini didasarkan pada hasil analisis kebutuhan berupa wawancara terhadap guru mata pelajaran Biologi kelas XII SMA Negeri 1 Kepahiang yang menyatakan bahwa materi fotosintesis ini adalah materi yang cukup sulit untuk dipahami oleh peserta didik dan juga kurang menarik. Menurut Kose (2008) pada materi fotosintesis banyak terjadi miskonsepsi. Hal tersebut menunjukkan bahwa materi fotosintesis sulit dipahami, selain itu Kurniawan (2011) menyatakan bahwa gambargambar pada materi fotosintesis dalam buku teks pelajaran, tidak dapat menjelaskan tahapan-tahapan dalam proses fotosintesis dengan jelas.

4. Miskonsepsi yang sering terjadi pada materi fotosintesis adalah karena penggunaan istilah reaksi gelap dan reaksi terang yang akan menimbulkan mindset bahwa reaksi terang berlangsung di siang hari dan reaksi gelap terjadi di malam hari, padahal reaksi fotosintesis baik itu reaksi terang maupun reaksi gelap hanya berlangsung di siang hari. Hal ini sejalan dengan pendapat Sularno (2009) yang menyatakan bahwa istilah gelap dan terang (light and darkreactions) seringkali membuat persepsi yang salah. Pada pembelajaran pemula sering salah paham bahwa reaski gelap terjadi pada malam hari dan reaksi terang terjadi pada siang hari. Padahal fotosintesis hanya terjadi pada siang hari.

5. Dua tahapan fotosinteis yang melatarbelakangi penggunaan istilah tersebut adalah; 1) Tahapan bergantung cahaya (light dependent stage) yang kemudian disebut reaksi terang (light reaction) dan 2) Tahapan tidak bergantung cahaya (light independent stage). Ada baiknya istilah tersebut diganti dengan penggambaran proses reaksi yang terjadi pada fotosintesis. Istilah terang diganti dengan reaksi penangkapan energi (the energy capturing reaction) dan istilah gelap diganti dengan fiksasi carbon (the fixtation of carbon reaction). 


\section{b. Desain Multimedia Interaktif Materi Fotosintesis Menggunakan Macromedia Flash}

Multimedia interaktif yang dikembangkan mengandung unsur 3 (tiga) bagian utama yang telah disesuaikan dengan kebutuhan analisis peneliti yaitu: Bagian pertama merupakan pendahuluan yang terdiri dari halaman pembuka. Bagian kedua merupakan halaman profil penulis, dan bagian ketiga yaitu menu utama yang berisi kurikulum pembelajaran materi fotosintesis kelas XII SMA dan sub bab materi fotosintesis. Adapun kerangka multimedia interaktif materi fotosintesis kelas XII SMA yang dibuat dalam bentuk flowchart dapat dilihat pada Gambar 1.

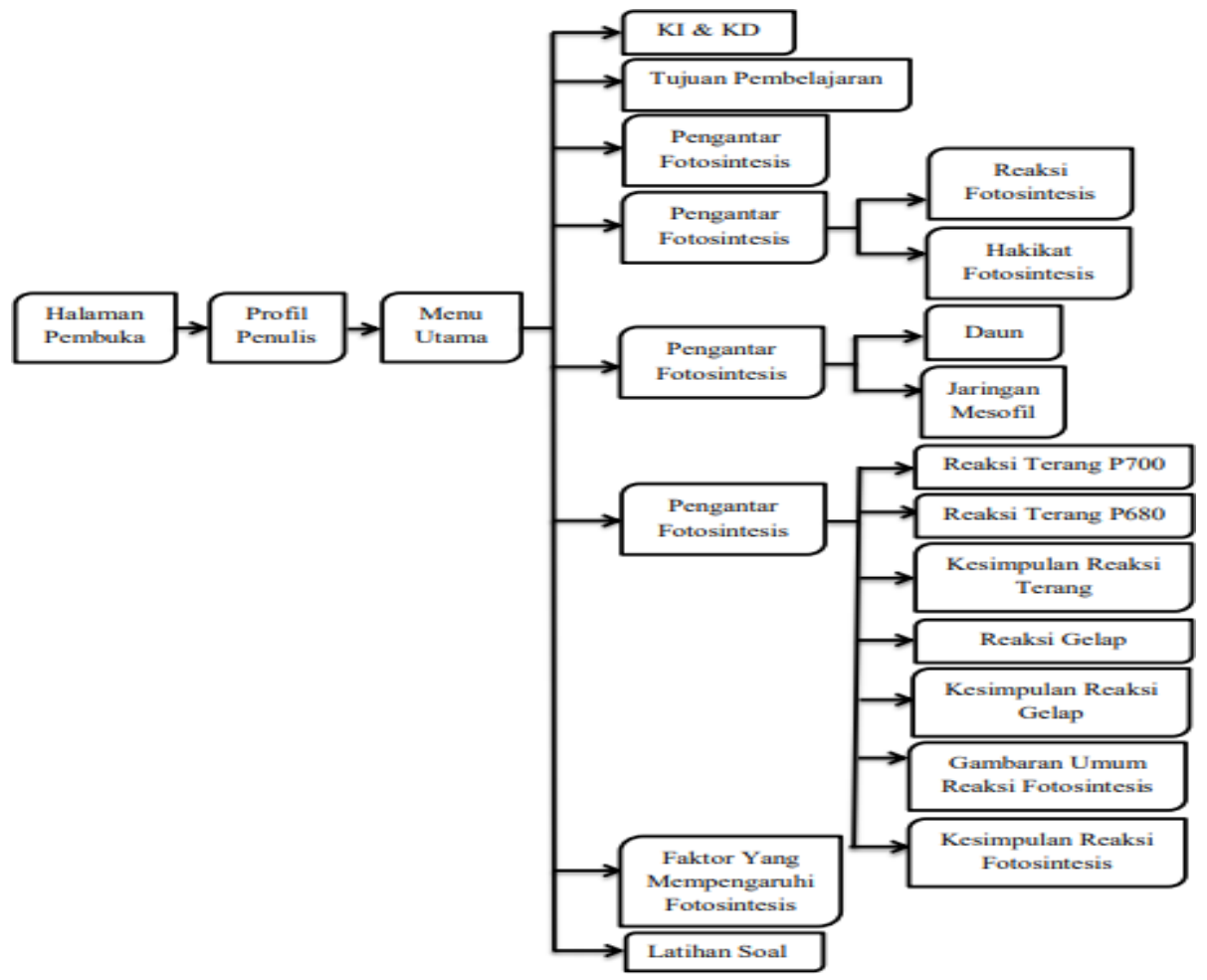

\section{Gambar 1. Flowchart Multimedia Interaktif Materi Fotosintesis Kelas XII SMA}

Hasil desain multimedia interaktif materi fotosintesis kelas XII SMA ini dapat dibuka dengan menggunakan aplikasi flash player pada laptop atau komputer dan autorun menggunakan $C D$ (Compact Disc) dengan format file .wsf dan .exe yang berukuran 4,51 MB, dengan desain sebagai berikut:

1) Pada halaman pembuka multimedia interaktif ini terdapat tulisan animasi selamat datang dan tombol "Next" di sudut kanan bawah halaman, tombol ini sebagai berguna untuk memulai menampilkan halaman berikutnya.

2) Setelah tombol "Next"diklik, maka akan ditampilkan halaman profil penulis yang berisi informasi mengenai penulis.

3) Setelah diklik tombol "Next" lagi pada halaman tersebut maka akan muncul halaman menu materi, pada halaman ini terdapat sub menu yang meliputi beberapa tombol menu materi yang bisa di pilih sesuai dengan kebutuhan user (pengguna), setelah tombol sub menu di klik maka akan muncul materi yang sesuai dengan judul pada tombol yang dipilih user tadi. Tombol sub menu tersebut yaitu "KI \& KD", "Tujuan Pembelajaran", "Pengantar Fotosintesis", "Pengertian Fotosintesis", "Tempat Terjadinya Fotosintesis", "Mekanisme Fotosintesis", "Faktor yang Mempengaruhi Fotosintesis", dan "'Latihan Soal". 
4) Pada setiap halaman menu multimedia interaktif terdapat tombol navigasi yaitu, tombol " Home" yang berada di sisi kiri atas setiap halaman yang berfungsi untuk kembali ke halaman menu utama, tombol " Next" yang terletak pada sudut kanan bawah setiap halaman yang berfungsi untuk menuju ke halaman selanjutnya, kecuali pada halaman latihan soal, dimana pada halaman tersebut tombol "Next" terletak disudut kanan bawah halaman tetapi posisinya bersebrangan dengan tombol "Back" sedangkan pada halaman lainnya tombol "Back" terletak di sudut kanan bawah halaman dengan posisi di samping tombol "Next".

Pada setiap halaman multimedia interaktif terdapat berbagai variasi penyampaian materi, yaitu berupa audio yang berisi penjelasan materi, animasi, teks, dan gambar.

\section{c. Validasi Ahli dan Revisi}

Validasi multimedia interaktif materi fotosintesis ini dilakukan menggunakan lembar angket validasi, validasi ini dilakukan dua orang dosen, satu orang dosen biologi sebagai ahli materi dan satu orang dosen fisika sebagai ahli media dan satu guru mata pelajaran biologi di SMA N 1 Kepahiang sebagai ahli praktisi. Validasi multimedia interaktif ini menilai beberapa komponen meliputi aspek format, isi/materi dan kebahasaan. Adapun hasil validasi multimedia interaktif yang dikembangkan dapat dilihat pada Tabel 2 .

Tabel 2. Hasil Validasi Multimedia Interaktif yang Dikembangkan

\begin{tabular}{clcc}
\hline No & \multicolumn{1}{c}{ Validator } & Presentase \% & Kategori \\
\hline 1. & Ahli Materi & $94,64 \%$ & $\begin{array}{c}\text { Sangat } \\
\text { Layak } \\
\text { Sangat } \\
\text { 2. }\end{array}$ Ahli Media \\
3. & $86,36 \%$ & $\begin{array}{c}\text { Sangat } \\
\text { Layak }\end{array}$ \\
\hline SMAN 1 Kepahiang) & $91,07 \%$ & $\begin{array}{c}\text { Sangat } \\
\text { Layak }\end{array}$ \\
\hline
\end{tabular}

Rata-rata presentase kelayakan oleh validator yaitu sebesar 89,69\% dengan kategori sangat layak. Berdasarkan hasil validasi multimedia interaktif yang dikembangkan menunjukkan keputusan uji yaitu sangat layak tetapi perlu dilakukan revisi berdasarkan saran dan komentar yang diberikan oleh kedua validator. Hal tersebut sesuai dengan penyataan Arikunto (2011) yang menyatakan bahwa media pembelajaran dikatakan valid apabila hasil analisis sesuai dengan kriteria yang telah ditentukan sebelumnya setelah melewati dua validator yaitu validator media dan validator konten (materi). Hasil yang sama juga dilaporkan oleh Cahyo (2015) yang mengembangkan multimedia pembelajaran interaktif mata pelajaran gambar teknik di SMK N 1 Pleret diperoleh presentase validasi sebesar $86,50 \%$ dengan kategori sangat layak dan juga penelitian Budiarta (2010) yang mengembangkan multimedia interaktif model ADDIE untuk meningkatkan motivasi belajar sejarah siswa kelas X-1 semester genap di SMAN 1 Sukasada, Buleleng, Bali diperoleh presentase validasi sebesar $91,9 \%$ dengan kategori sangat layak.

Adapun saran dan revisi dari ketiga validator yaitu 1) perbaikan terhadap konsep pengertian reaksi fotosintesis menjadi lebih sederhana dan mudah dipahami, 2) mengganti soal latihan pada multimedia interaktif agar memenuhi kategori soal HOTS untuk peserta didik kelas XII SMA, 3) mengganti desain tombol "Next" agar lebih proporsional, dan 4) mengganti desain background multimedia interaktif agar tulisan yang ada pada halaman dapat dibaca dengan 
jelas oleh user (pengguna). Hasil revisi multimedia yang dikembangkan dapat dilihat pada Tabel 3 .

Tabel 3. Hasil Revisi Multimedia yang Dikembangkan

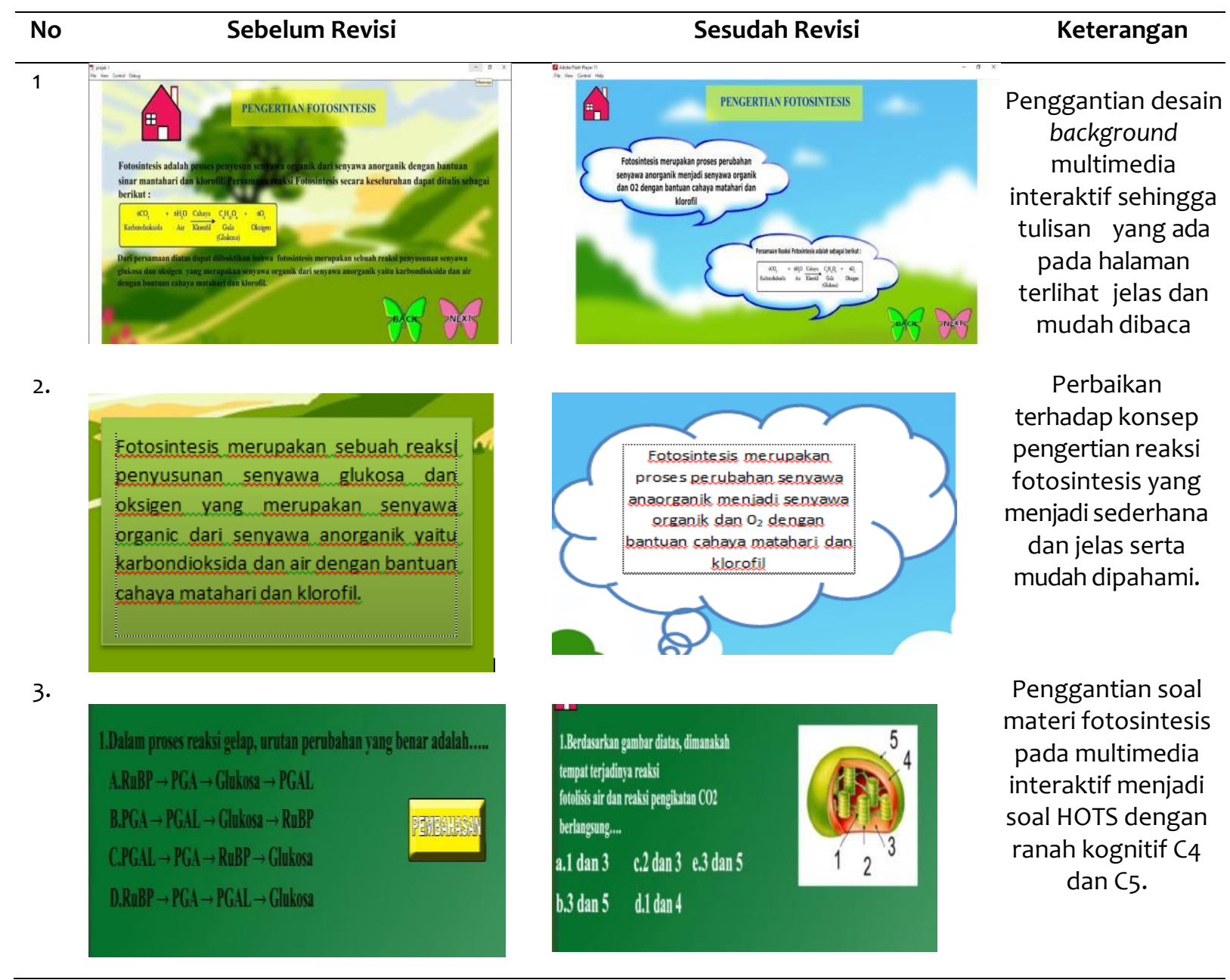

\section{Gambar 3. Perbedaan Multimedia Interaktif Sebelum dan Setelah Revisi Desain Berdasarkan Analisis Hasil Validasi}

\section{d. Analisis Hasil Validasi Uji Lapangan Skala Kecil}

Pada uji coba lapangan berupa uji respon multimedia interaktif yang diujicobakan kepada 10 orang peserta didik. Sepuluh orang tersebut, diambil dari peserta didik kelas XII MIPA SMA Negeri 1 Kepahiang. Data hasil uji respon multimedia interaktif diperoleh dari hasil penilaian 10 orang peserta didik kelas XII MIPA SMA Negeri 1 Kepahiang dapat dilihat pada Tabel 4. Rerata persentase uji respon multimedia interaktif yang diperoleh yaitu sebesar $86,73 \%$ dengan kriteria sangat valid/layak. Hal yang sama juga dilaporkan oleh Fathiyati (2012) multimedia interaktif Macromedia Flash yang dikembangan pada pembelajaran Biologi materi pokok sistem reproduksi manusia bagi siswa SMA/MA kelas XI semester 2 berdasarkan uji respon adalah sangat baik dengan hasil uji respon sebesar $88,07 \%$ dan Hamdani (2017) hasil angket respon siswa menunjukkan bahwa media media pembelajaran menggunakan Macromedia Flash Profesional 8 materi sistem ekskresi pada manusia yang dikembangan sangat layak digunakan pada proses 
pembelajaran dengan persentase sebesar 86,04\%. Adapun hasil uji lapangan skala kecil (uji respon) multimedia interaktif yang dikembangkan dapat dilihat pada Tabel 4.

Tabel 4. Hasil Uji Lapangan Skala kecil (uji respon)

\begin{tabular}{clcc}
\hline No & Komponen yang di nilai & Persentase & Kriteria \\
\hline 1. & Penyajian Materi & $89,25 \%$ & Sangat Layak \\
2 & Kebahasaan & $83.75 \%$ & Layak \\
3. & Tampilan & $87.19 \%$ & Sangat Layak \\
\hline & Rata-rata & $86,73 \%$ & Sangat Layak \\
\hline
\end{tabular}

Dengan hasil uji kelayakan tersebut maka multimedia interaktif materi fotosintesis kelas XII SMA yang telah dibuat sangat layak digunakan untuk proses pembelajran biologi khususnya materi fotosinteis di kelas XII SMA. Hal ini sesuai dengan pernyataan Akbar (2013) yang menyatakan bahwa media pembelajaran dapat dikatakan sangat layak bila rata-rata persentase dari angket validasi ahli media, ahli materi dan uji respon diatas $86 \%$. Dengan demikian, secara keseluruhan baik dari ahli materi, ahli media, dan ahli praktisi serta keterbacaan oleh peserta didik kelas XII MIPA SMA Negeri 1 Kepahiang menyatakan bahwa, produk multimedia interaktif materi fotosintesis kelas XII SMA dengan menggunakan software Macromedia Flash 8 ini layak untuk digunakan sebagai media pembelajaran pada mata pelajaran biologi kelas XII MIPA SMA pada proses pembelajaran didalam kelas maupun di luar kelas.

Berdasarkan lembar validasi dari sepuluh orang siswa kelas XII MIPA SMA Negeri 1 Kepahiang, didapatkan beberapa komentar mengenai multimedia interaktif yang dibuat, komentar-komentar dari peserta didik meliputi berbagai aspek multimedia interaktif, diantaranya peserta didik berkomentar mengenai animasi yang dimuat dalam multimedia interaktif, animasi tersebut dinilai memberikan dampak positif dalam memahami materi fotosintesis karena menampilkan gambar dan serta audio penjelasan, kemudia terdapat juga beberapa komentar yang sifatnya membangun, di antaranya multimedia interaktif yang dikembangkan hendaknya tidak terbatas pada materi fotosintesis saja, kemudia warna dan jenis font tulisan yang dimuat dalam multimedia interaktif tersebut kurang menarik dilihat.

Multimedia interaktif materi fotosintesis yang telah dibuat mempunyai karakteristik sebagai berikut:

1) Bersifat interaktif, dimana pengguna (user) dapat bernavigasi secara bebas, artinya pengguna dapat mengontrol atau mengendalikan multimedia sesuai dengan keinginan dan kebutuhannya serta multimedia mampu menerjemahkan perintah tersebut, dengan kata lain ada hubungan timbal balik antara pengguna dan multimedia.

2) Multimedia interaktif memuat hubungan terstruktur yang meliputi beberapa media, artinya multimedia tidak hanya memuat teks saja, melainkan memuat gambar, audio, animasi, serta grafik komputer yang berhubungan dengan materi fotosintesis kelas XII SMA.

3) Multimedia interaktif materi fotosintesis ini dapat dipresentasikan pada sebuah layar komputer berbasis web maupun non-web.

4) Peserta didik yang belajar materi fotosintesis dnegan menggunakan multimedia interaktif ini dapat membangun pengalaman dan pengetahuannya secara mandiri tanpa arahan dari guru. Sehingga konsep-konsep materi yang dipelajarinya akan lebih bermakna karena melibatkan pengalaman inderanya secara langsung. 
Hal tersebut sejalan dengan pendapat Warsita (2008) yang menyatakan bahwa multimedia interaktif memiliki karakteristik diantaranya adalah ; 1) Dapat digunakan secara acak, disamping secara linier; 2) Dapat digunakan sesuai dengan keinginan peserta didik, disamping menurut cara seperti yang dirancang oleh pengembangnya; 3) Gagasan-gagasan sering disajikan secara relistik dalam konteks pengalaman peserta didik, relevan dengan kondisi peserta didik, dan dibawah kendali peserta didik (user); 4) prinsip-prinsip teori belajar kognitif dan konstruktivisme diterapkan dalam pengembangan dan Pemanfaatan bahan pembelajaran; 5) Belajar dipusatkan dan diorganisasikan menurut pengetahuan kognitif sehingga pengetahuan terbentuk pada saat digunakan; 6) Bahan belajar menunjukkan interaktivitas peserta didik yang tinggi; dan 7) Sifat bahan yang mengintegrasikan kata-kata dan contoh dari banyak sumber media.

Di dalam multimedia interaktif ini juga terdapat lima soal latihan dengan jenis soal pilihan ganda untuk peserta didik yang dibuat dengan tipe latihan soal HOTS pada ranah kognitif $\mathrm{C}_{4}$ dan $C_{5}$ yang dibuat berdasarkan hasil analis kurikulum pada materi Metabolisme sub materi fotosintesis, analisis kurikulum untuk membuat latihan soal tersebut dilakukan untuk menghasilkan latihan soal yang mampu mengasah kemampuan berfikir kritis peserta didik atau pengguna multimedia interaktif materi fotosintesis, selain itu ada beberapa latihan soal yang diadaptasi dari soal olimpiade nasional biologi (OSN Biologi) beberapa tahun terakhir dengan kategori soal HOTS. Pada setiap halaman latihan soal terdapat tombol pembahasan yang menampilkan pembahasan soal, penambahan tombol "Pembahasan" ini bertujuan untuk memberikan pembahasan terhadap jawaban dari soal yang sedang dikerjakan oleh peserta didik atau pengguna. Pengemasan produk akhir multimedia interaktif materi fotosintesis yang dikemas dalam CD atau bisa juga disimpan di dalam flashdisk serta dapat juga di akses pada web Program Studi Pendidikan Biologi Universitas Bengkulu, hal tersebut sangat memungkinkan bagi pengguna untuk menggunakan multimedia interaktif ini dimana saja dan kapan saja secara mandiri

\section{KESIMPULAN}

Multimedia interaktif ini berisi 23 halaman, di mana 20 halaman yang berisi materi fotosintesis kelas XII SMA serta latihan soal dimuat dalam tombol menu yang terletak di halaman utama. Adapun tombol menu tersebut yaitu tombol "KI \& KD", "Tujuan Pembelajatan", "Pengantar Fotosintesis", Pengertian Fotosintesis", "Tempat Terjadinya Fotosintesis, "Mekanisme Fotosintesis, "Faktor Yang Mempengaruhi Fotosintesis", dan tombol "Latihan Soal". Pada masing-masing halaman terdapat tombol navigasi yaitu tombol "Next", "Back", dan "Home". Kelayakan multimedia interaktif materi fotosintesis kelas XII SMA berdasarkan penilaian validator dengan presentase kelayakan rata-rata sebesar 90,69\% dengan kategori sangat layak. Uji lapangan skala kecil yang berupa uji respon mendapatkan presentase kelayakan sebesar $86,73 \%$ dengan kategori sangat baik.

\section{DAFTAR PUSTAKA}

Akbar, S. (2013). Instrumen Perangkat Pembelajaran. Bandung: Rosdakarya

Fathiyati, R., \& Utami, R. P. (2012). Pengembangan media pembelajaran Biologi berbasis macromedia flash sebagai sumber belajar bagi siswa SMA/MA kelas XI semester 2 Materi pokok sistem reproduksi manusia. In Prosiding Seminar Biologi (Vol. 9, No. 1).

Hamdani, R., Karno, R., \& Afifah, N. (2017). Pengembangan Media Pembelajaran Biologi Dengan Menggunakan Macromedia Flash Profesional 8. Jurnal Ilmiah Mahasiswa FKIP Prodi Biologi, 3(1). 
Kose, S. (2008). Diagnosing Student Misconceptions: Using Drawings As a Research Method. World Applied Sciences Journal, 3(2), 283-293. doi: 10.12691/education-6-10-15

Kusumawanto, F. (2011) Pengembangan Media Pembelajaran Macromedia Flash Menjelaskan Proses Dasar Perlakuan Logam pada Mata Pelajaran Kompetensi Dasar Teknik Mesin di SMK N 2 Pengasih Kulon Progo Yogyakarta. (Skrips, Universitas Negeri Yogyakarta) Retrieved from https://eprints.uny.ac.id/28336/1/Fidrian\%20Kusumawanto\% 2006503241016.pdf

Kurniawan, M., Izzati, M., \& Nurchayati, Y. (2010). Kandungan Klorofil, Karotenoid, dan Vitamin C Pada Beberapa Spesies Tumbuhan Akuatik. Anatomi Fisiologi, 18(1), 28-40. doi: 10.14710/baf.v18i1.2614.

Mayer, R. E. (2009). Multimedia Learning 2nd Edition. New York: Cambridge University Press Meitantiwi, E. Y., Mohammad, M., \& Nanik, D. N. (2015). Pengembangan Multimedia.

Noer, M. (2010). Hypnoteaching: For Success Learning. Yogyakarta: Pedagogia Riduwan. (2015). Skala Pengukuran Variabel-Variabel Peneltian. Bandung: Alfabeta.

Pembelajaran Tutorial Menggunakan Software Macromedia Flash Pada Materi Sifat Keperiodikan Unsur Untuk Pembelajaran Kimia Kelas X MIA SMA. Jurnal Pendidikan Kimia (JPK), 4(1), 5967.

Sari, R. M., Kasrina, K., \& Jumiarni, D. (2020). Pengembangan Buku Saku Berbasis Penelitian Pengaruh Ampas Ebu Sebagai Media Tanam Jamur Tiram (Pleurotus Ostreatus) untuk Mata Kuliah Mikrobiologi. Diklabio: Jurnal Pendidikan dan Pembelajaran Biologi, 4(1), 86-93. doi: 10.33369/diklabio.4.1.86-93

Sulamtina, P., Jalmo, T., \& Yolida, B. (2017). Identifikasi Miskonsepsi Siswa pada Materi Fotosintesis dan Respirasi. Jurnal Bioterdidik: Wahana Ekspresi Ilmiah, 5(2).17:18. doi:

Sularno, S. (2018). Reaksi Penangkapan Energi dan Reaksi Fiksasi Karbon sebagai Istilah Alternatif Pengganti Reaksi Gelap dan Terang dalam Proses Fotosintesis. Menara IImu, 1(15), 42-46. doi: $10.31227 / 0 s f . i o / 6 \mathrm{crdm}$

Sutopo, A. H.(2003). Multimedia Interaktif dengan Flash. Yogyakarta: Graha Ilmu Warsita, B. (2008). Teknologi Pembelajaran: Landasan \& Aplikasinya, Jakarta: Rineka

\section{Dwi Widyawati}

Mahasiswa Universitas Bengkulu, aktif melakukan penelitian pada bidang Pendidikan IPA, dapat dihubungi melalui email: dwiwidya70o@gmail.com

\section{Dewi Jumiarni}

Universitas Bengkulu, aktif melakukan penelitian pada bidang Pendidikan IPA

\section{Irwandi Ansori}

Universitas Bengkulu, aktif melakukan penelitian pada bidang Pendidikan IPA 